\title{
Prevalence of COPD among women and relation with cooking fuel choice in Ouagadougou, Burkina Faso
}

\author{
S. Adama, ${ }^{1,2}$ M. Nicolas, ${ }^{1}$ K. Benoit, ${ }^{1}$ B. Gisèle, ${ }^{3,4}$ C. Bouland ${ }^{2}$ \\ 1Département de Santé Publique, Université Joseph Ki-Zerbo, Ouagadougou, Burkina Faso; ${ }^{2}$ Centre de Recherche \\ en Santé Environnementale et Santé au Travail, Ecole de Santé Publique, Université Libre de Bruxelles, Brussels, \\ Belgium; 'unité de Formation et de Recherche en Sciences de la Santé, Université Joseph Ki-Zerbo, Ouagadougou, \\ ${ }^{4}$ Service de Pneumo-phtisiologie, Centre Hospitalier Universitaire Yalgado Ouédraogo, Ouagadougou, Burkina Faso
}

BACKGROUND: According to the WHO, chronic obstructive pulmonary disease (COPD) will become the third leading cause of death by 2030 . In sub-Saharan Africa, the burden of the disease is unknown. We assessed the prevalence and the factors associated with COPD and chronic bronchitis among women in charge of household cooking.

METHODS: A cross-sectional population survey was conducted. We randomly selected women aged $\geq \mathbf{1 8}$ years in charge of cooking in their household. COPD was defined as post-bronchodilator $\mathrm{FEV}_{1} / \mathrm{FVC}$ (forced expiratory volume in $1 \mathrm{sec} /$ forced vital capacity) ratio of $<0.70$; chronic bronchitis was defined as cough with sputum of at least 3 months in the year for at least 2 consecutive years.
RESULTS: Of the 1705 women interviewed, 835 were selected to perform spirometry and 564 provided an acceptable test result. The prevalence of COPD was $1.1 \%$ and that of chronic bronchitis was $1.2 \%$. COPD prevalence was higher among women using biomass, women aged $>40$ years, those had been cooking or had been exposed to toxic gases for more than 30 years. After adjustment, only biomass fuel use and exposure to toxic products were found to be associated with COPD.

CONCLUSION: Urgent action is need to accelerate the transition to the other sources of energy.

KEY WORDS: indoor air pollution; biomass fuels; women's health; sub-Saharan Africa
IN SEVERAL LOW AND MIDDLE-INCOME countries, in addition to traditional infectious diseases, non-communicable diseases are becoming increasingly important, in conjunction with socio-cultural changes, escalating urbanisation and unhealthy behavioural and lifestyle patterns. ${ }^{1,2}$ Heart disease, stroke, lung disease and cancers are among the top five causes of death worldwide, and one quarter to one third of these deaths are due to air pollution. ${ }^{3}$ In 2012, more than 6 million deaths from these diseases were related to air pollution. ${ }^{3}$

In developing countries, nearly 3 billion people continue to use biomass fuels (wood, agricultural residues, animal dung, charcoal) to satisfy their fuel needs (cooking food, heating water or heating space), leading to the untimely death of about 4.3 million people. ${ }^{4}$ These fuels are often used in unhealthy conditions such as open fires or inefficient fireplaces and poorly ventilated kitchens. ${ }^{5}$ The smoke released contains harmful pollutants, including fine particle matter with diameter of less than $2.5 \mu \mathrm{m}\left(\mathrm{PM}_{2.5}\right)$, carbon monoxide (CO) and polycyclic aromatic hydrocarbons (PAHs). ${ }^{6,7}$ In the city of Ouagadougou, Burkina Faso, concentrations of $\mathrm{PM}_{2.5}$ produced in households were found to be higher than the WHO indoor air quality threshold of $25 \mu \mathrm{g} / \mathrm{m}^{3}$ per $24 \mathrm{~h}$. The average $\mathrm{PM}_{2.5}$ concentrations for $24 \mathrm{~h}$ were 110.69 $\mu \mathrm{g} / \mathrm{m}^{3}$ in outdoor kitchens, $95.69 \mu \mathrm{g} / \mathrm{m}^{3}$ in households using traditional stoves and wood, $62.54 \mu \mathrm{g} / \mathrm{m}^{3}$ in households using wood and $27.62 \mu \mathrm{g} / \mathrm{m}^{3}$ in households using improved stoves and charcoal. 8,9 As children under 5 years, women and the elderly spend much more time at home or near open fires or cookstoves than others, they are most likely to be affected by indoor air pollution from biomass-based fuel used for cooking. ${ }^{10,11}$

According to the WHO, 64 million people suffered from chronic obstructive pulmonary disease (COPD) in 2004, including 3 million deaths. ${ }^{12}$ By 2030, this disease is expected to become the third leading cause of death in the world. ${ }^{12}$ The worldwide prevalence of COPD is growing faster among women than men. Over the past two decades, COPD-related mortality rates have also increased faster in women, and since 2000 more women than men have died from COPD. ${ }^{13}$ Epidemiological studies have shown a strong association between biomass use and COPD occurrence among women. ${ }^{14-16}$ Women exposed to

Correspondence to: Sana Adama, Département de Santé Publique, Université Joseph Ki-Zerbo, Avenue Charles de Gaulle, Zogona, Ouagadougou 03 BP 7021, Burkina Faso. e-mail: adou_sanette@yahoo.fr

Article submitted 24 September 2019. Final version accepted 11 February 2020. 
biomass smoke are three times more likely to suffer from COPD than those who cook with clean fuels. $7,17,18$

Although the relationship between COPD and the exposure to biomass smoke from cooking has been largely acknowledged, studies have shown that COPD remains an under-diagnosed pathology. Studies on COPD prevalence in sub-Saharan Africa are extremely scarce. Our study aims to determine the prevalence of COPD among women in charge of cooking in the urban area of Ouagadougou, Burkina Faso, and to examine its association with the main cooking fuel used.

\section{METHODS}

Study area and target population

This study is part of a larger research project (IRDC project \#107347) focused on the relationship between indoor air pollution and respiratory diseases in Ouagadougou, Burkina Faso, led by Joseph Ki-Zerbo University. The project received the approval of Burkina Faso Ethics Committee for Health Research, Ouagadougou, Burkina Faso (no 2015-9-114).

Between March 2017 and September 2018, a crosssectional, population-based study was carried out in three neighbourhoods of Ouagadougou: Kilwin, Tampouy and Tanghin. Ouagadougou is the largest city and the capital city of Burkina Faso. The choice of the three sites is explained by their socio-spatial characteristics. All three are residential and fairly representative of the districts of Ouagadougou in terms of socio-economic characteristics and models of space occupation. ${ }^{19}$ Eligible participants were women or girls aged at least 18 years, with a minimum of 2 years of residence in the neighbourhood.

\section{Sample size}

According to 2012 estimates, the population of Ouagadougou was 1915102 inhabitants, ${ }^{20}$ distributed over 55 neighbourhoods and 12 districts. Using the statcalc tool of Epi Info ${ }^{\mathrm{TM}}$ v7.2.2.2 (Centers for Disease Control and Prevention, Atlanta, GA, USA) for calculating sample size for population survey or descriptive study, based on an expected prevalence of $8.5 \%,{ }^{21}$ with $2 \%$ acceptable margin for error and $95 \%$ confidence intervals (CIs), and allowing for a $10 \%$ refusal to participate in the study, we estimated that 822 subjects would be required to be recruited in the survey.

However, for the purposes of the project, the sample size was determined and based on the number of cases needed to identify a possible statistical relationship between exposure to pollutants from biomass combustion and COPD. The number of cases needed were therefore calculated using STATA v13.1 (StataCorp, College Station, TX, USA); we then deducted the number of women to be included in the cross-sectional survey. The parameters used for the calculation at an alpha risk of $5 \%$, power of $80 \%$, odds ratio (OR) of 2 and $95 \%$ CI. We assumed the frequency of exposure among controls to be $70 \%$, as $73 \%$ of households in the municipality of Ouagadougou used mainly wood or charcoal for cooking. ${ }^{20}$ Considering two independent populations, the number of cases required was 186 . For an average COPD prevalence of $8.5 \%,{ }^{21}$ and assuming a non-participation rate of $10 \%$, we found that 2407 participants were required in the cross-sectional survey to obtain 186 cases of COPD. As no sampling frame was available for the neighbourhoods in question, the sampling technique used was the itineraries method. ${ }^{22}$

\section{Data collection}

The study was conducted in two steps. The first step was to diagnose suspected cases of COPD or asthma by using a symptom-based questionnaire. We selected households and women or girls aged at least 18 years in charge of household cooking with a minimum of 2 years of residence in the neighbourhood. Data on energy choices for cooking, socio-cultural, economic, demographic and personal characteristics of the women participants were collected using a standardised questionnaire. Objective respiratory health data were also collected. Respiratory health information was collected from participants with symptoms of obstructive respiratory diseases such as COPD, including chronic bronchitis (CB) and asthma. The Global Initiative for Chronic Obstructive Lung Disease (GOLD) COPD self-testing questionnaire, "Could It Be COPD?", 23 adapted by the Haute Autorité de Santé (HAS), ${ }^{24}$ was used in our study for the diagnosis of suspected cases of COPD based on symptoms. This questionnaire is an appropriate tool for COPD screening in the general population. ${ }^{25}$

The questionnaire used for the medical monitoring of occupational asthma in workers exposed to diisocyanate in Quebec, ${ }^{26}$ combined with an adapted questionnaire from Venables et al. ${ }^{27}$ was used for asthma screening in our study population. CB diagnosis was made using the Medical Research Council (MRC) questionnaire. ${ }^{28}$ Chronic bronchitis has been defined as a sputum cough that lasts at least 3 months in the year for at least 2 consecutive years. ${ }^{15}$

On completion of the first stage, suspected cases of COPD, $\mathrm{CB}$ and asthma were identified based on symptoms. The second step was to confirm the suspected cases of COPD using spirometry. Those who had positive responses to three of the five questions of the GOLD questionnaire, those with at least three positive responses to asthma screening questionnaire, and those diagnosed with $\mathrm{CB}$ were identified as suspected cases.

A portable spirometer, the Spirobank II advanced, 
was used. Spirometry was performed seated by trained physicians according to the American Thoracic Society (ATS) criteria. ${ }^{29}$ The expected values were calculated based on data from the National Health and Nutrition Examination Survey (NHANES III).

At least three measures had to be carried out for each participant and the highest results were considered. If the ratio of forced expiratory volume in the 1 $\sec \left(\mathrm{FEV}_{1}\right)$ to forced vital capacity (FVC) was $>0.70$, $200 \mu \mathrm{g}$ of salbutamol were administered, ${ }^{30}$ with the consent of the participant. In these cases, postbronchodilation spirometry was performed at least $10 \mathrm{~min}$ after bronchodilator administration. COPD was defined as a post-bronchodilation $\mathrm{FEV}_{1} / \mathrm{FVC}$ of $<0.70$. The results were reviewed by a pulmonologist at the Yalgado Ouedraogo University Hospital.

\section{Data analysis}

Data were encoded using EpiData software (EpiData Association, Odense, Denmark). The sample description and analysis were performed using Stata software, v13.0. The dependent variables were COPD and CB. The independent variables analysed were cooking fuel, age, years of cooking, duration of cooking, location of the kitchen in the house, exposition to road traffic pollution, cigarette smoking status (active smoking and passive smoking), occupation (the exercise of any activity, other than cooking, that resulted in exposure to smoke, dust or toxic gases such as pesticide use in gardening, products used in dyeing, soap making, high road sweeping, etc.), burning of mosquito coils, incense burning, previous history of tuberculosis; these variables were selected based on literature review. ${ }^{16}$

To be able to correctly interpret the results of the survey, some variables were dichotomised as follows: the main cooking fuel used was dichotomised as biomass vs. liquefied petroleum gas (LPG); number of years of cooking was divided into two groups: 15 years and 30 years, as these were considered significant to develop chronic diseases such as COPD. Participants were divided in terms of age into two groups: $\leq 40$ years and $\geq 40$ years, as some studies shown that COPD is more frequent after 40 years. Kitchens were divided into four categories in terms of location: indoor (kitchen in the main building), outdoor closed (in a separate building), open air (outdoor kitchen with fewer than three walls) and unspecified location. Passive smokers, i.e., those exposed to smoke from other people's cigarettes, cigars or pipes was divided into three groups: those not exposed, those exposed at home or at work and those exposed both at home and at work. Other variables were dichotomised in terms of 'yes' and 'no' categories.

We used conventional statistics to describe the sample. Independent variables were described using frequencies or medians. Prevalence of COPD and CB was estimated and presented as numbers and percentages. The association between independent variables (including potential confounding factors) and the variables of interest (COPD and $\mathrm{CB}$ ) was assessed using Pearson's $\chi^{2}$ test. In case of nonapplicability of the $\chi^{2}$ test (expected $<5$ ), Fisher's exact test was used. We performed bivariate analysis to study the associations between each independent variable (the main cooking fuel and potential confounding factors) and COPD, following which multivariate logistic regression was performed. All variables that were associated with a $P$ value of $<0.2$ in bivariate analysis were then considered for inclusion in a multivariable logistic regression model. ORs and their $95 \%$ CIs were calculated. $P<0.05$ was considered significant.

\section{RESULTS}

Of the 2407 subjects required, 1735 were finally selected for this study and 1705 participants completed the questionnaire. Among these, 835 met the selection criteria for spirometry. At the end of the study, 564 women had valid test results; 224 participants did not perform the lung function test, either because they refused or they were inaccessible, very busy or had moved or were travelling during the study period; 47 invalid tests were excluded.

In our sample, $59.5 \%$ of the women $(n=1015)$ reported the use of biomass-based fuels as their main cooking fuel and $40.48 \%(n=689)$ reported using mainly LPG for cooking (Table 1 ). About $33 \%$ of the women interviewed were at least 40 years old, $23 \%$ reported cooking indoors and $52 \%$ in open air kitchens. Around $46 \%$ of the participants reported cooking for more than $2 \mathrm{~h}$ a day, $71 \%$ for at least 15 years and $28 \%$ for at least 30 years. About $36 \%$ were exposed to environmental tobacco smoke at home or/ and at the workplace.

Using spirometry, we diagnosed 26 cases of airway obstruction, including 12 cases of COPD postbronchodilation. In terms of conditional probability, it may be inferred that the number of cases of airway obstruction among the women selected for the spirometry and those who did not take part or who completed an invalid test would be 12 , with six cases of COPD. The actual prevalence of COPD in our study was $1.1 \%$ and the prevalence of airway obstruction was $2.3 \%$.

COPD prevalence was significantly different between biomass fuel users and LPG users, with a higher proportion in former group (Table 2). Among the 12 cases of COPD, 10 were at least 40 years old $(1.8 \%)$, with a significant difference $(P<0.001)$. CB was diagnosed among 20 participants $(1.2 \%$ prevalence). Prevalence was significantly higher among women who reported using biomass. However, we did not observe a significant difference in terms of age. No participant with $\mathrm{CB}$ was diagnosed with 
Table 1 Studied population characteristics

\begin{tabular}{|c|c|c|c|c|c|c|}
\hline \multirow[b]{2}{*}{ Variables } & \multirow[b]{2}{*}{ Categories } & \multicolumn{2}{|c|}{ Biomass $(n=1015)$} & \multicolumn{2}{|c|}{ LPG $(n=689)$} & \multirow[b]{2}{*}{$P$ value* } \\
\hline & & $n$ & $\%$ & $n$ & $\%$ & \\
\hline Age & $\geq 40$ years & 391 & 38.7 & 179 & 26.0 & $<0.001$ \\
\hline \multirow[t]{4}{*}{ Cooking place } & Indoor & 42 & 4.2 & 353 & 51.3 & $<0.001$ \\
\hline & Outdoor closed & 242 & 23.9 & 155 & 22.5 & \\
\hline & Open-air & 712 & 70.3 & 173 & 25.1 & \\
\hline & Unspecified & 17 & 1.6 & 8 & 1.2 & \\
\hline Cooking duration/day & $>2 \mathrm{~h}$ & 468 & 47.2 & 321 & 47.5 & 0.902 \\
\hline \multirow[t]{2}{*}{ Years of cooking } & $\geq 15$ years & 751 & 74.7 & 457 & 66.9 & 0.001 \\
\hline & $\geq 30$ years & 328 & 32.6 & 145 & 21.2 & $<0.001$ \\
\hline Smokers & Yes & 0 & 0 & 0 & 0 & - \\
\hline Passive smoking & Yes & 386 & 22.7 & 233 & 13.7 & 0.071 \\
\hline
\end{tabular}

$* P<0.05$ considered significant.

$\mathrm{LPG}=$ liquefied petroleum gas

COPD during spirometry. The overall prevalence of COPD, including CB was $2.2 \%$ (38 cases).

The univariate analysis showed that the combined prevalence of COPD and CB was significantly associated with the type of main cooking fuel used, age, number of years of cooking, the place of cooking meals and other types of exposure to toxic gases. Prevalence was higher among women using biomass, women aged $\geq 40$ years, women who had been cooking for $\geq 30$ years, and those cooking in the open air kitchens (Table 3). In the multivariate analysis, the use of biomass and the exercise of activities that resulted in exposure to other toxic gases were associated with COPD and CB (Table 4).

\section{DISCUSSION}

It should be noted that one of the major limitations of the study is the high non-participation rate among the women selected to undergo spirometry. The definition of the exposure variables might also have introduced some ranking bias. Exposure measures of the concentration of indoor air pollutants were not carried out and several women combined two or three types of fuel-like biomass-based fuel, as well as LPG. One of the strengths of this study was the adjustment for numerous confounders. Nevertheless, other parameters that were not included in the analysis may also have impacted the variables of interest.

This study found a low prevalence of COPD $(1.1 \%)$ and of $\mathrm{CB}(1.2 \%)$ among the study population. This prevalence is consistent with that found by

Table 2 Prevalence of COPD and chronic bronchitis in Ouagadougou, Burkina Faso

\begin{tabular}{lccr}
\hline & $\begin{array}{c}\text { Biomass } \\
(n=1015) \\
n(\%)\end{array}$ & $\begin{array}{c}\text { LPG } \\
(n=689) \\
n(\%)\end{array}$ & $P$ value* $^{*}$ \\
Variables & $12(1.2)$ & $0(0)$ & 0.002 \\
COPD & $17(1.7)$ & $3(0.4)$ & $<0.001$ \\
Chronic bronchitis & & & \\
$* P<0.05$ considered significant. & & \\
COPD $=$ chronic obstructive pulmonary disease; & LPG $=$ liquefied petroleum \\
gas.
\end{tabular}

Mbatchou et al. in the peri-urban area of Bafoussam in Cameroon, who noted a prevalence of around $1.6 \%$ for a sample of 300 women aged $\geq 40$ years. ${ }^{31}$ However, the CB prevalence reported in Cameroon was higher $(4 \%)$ than ours. Other studies conducted in Egypt, Uganda, Mexico and India found prevalences of respectively $6.6 \%, 16.8 \%, 2.4 \%$ and $2.5 \% .{ }^{32-35}$ These frequencies are higher than those observed in our population. One possible explanation for these differences could be related to the characteristics of the selected population such as age (women included in our survey were younger than those included in previous studies), gender composition (studies in Egypt and Uganda included both women and men), smoking status, and frequency, level and duration of exposure. Our study population was randomly constituted of non-smoking women. To note, smoking is not widespread among women in Burkina Faso.

The risk factors identified in our study were the type of main fuel used for cooking, age, numbers of years spent in household cooking, place for preparing meals and the exercise of other activities that lead to exposure to toxic gases. After adjustment, only the type of fuel used for cooking (biofuels) and exposure to other toxic gases remained significantly associated with the disease. In Egypt, Badway et al. observed a difference in COPD prevalence between subjects exposed to biomass smoke and those exposed to non-biomass smoke, with a higher proportion of COPD cases in the group exposed to biomass smoke, $P<0.0001 .^{32}$ Mbatchou et al. did not find a significant association between COPD and the use of wood as fuel for cooking, but between $\mathrm{CB}$ and wood use. ${ }^{31}$ Johnson et al. also observed a higher proportion of COPD among biomass users in India; however, this difference was not significant (OR 1.24, 95\% CI 0.36-6.64), the difference was also not significant among women who spend more than $2 \mathrm{~h}$ on home food cooking. ${ }^{33}$ Van Gemert et al. did not find a significant association between the type of fuel used and COPD, but with being a smoker. ${ }^{35}$ 
Table 3 Factors associated with COPD and chronic bronchitis in Ouagadougou, Burkina Faso on univariate analysis $(n=1705,1015$ biomass users)*

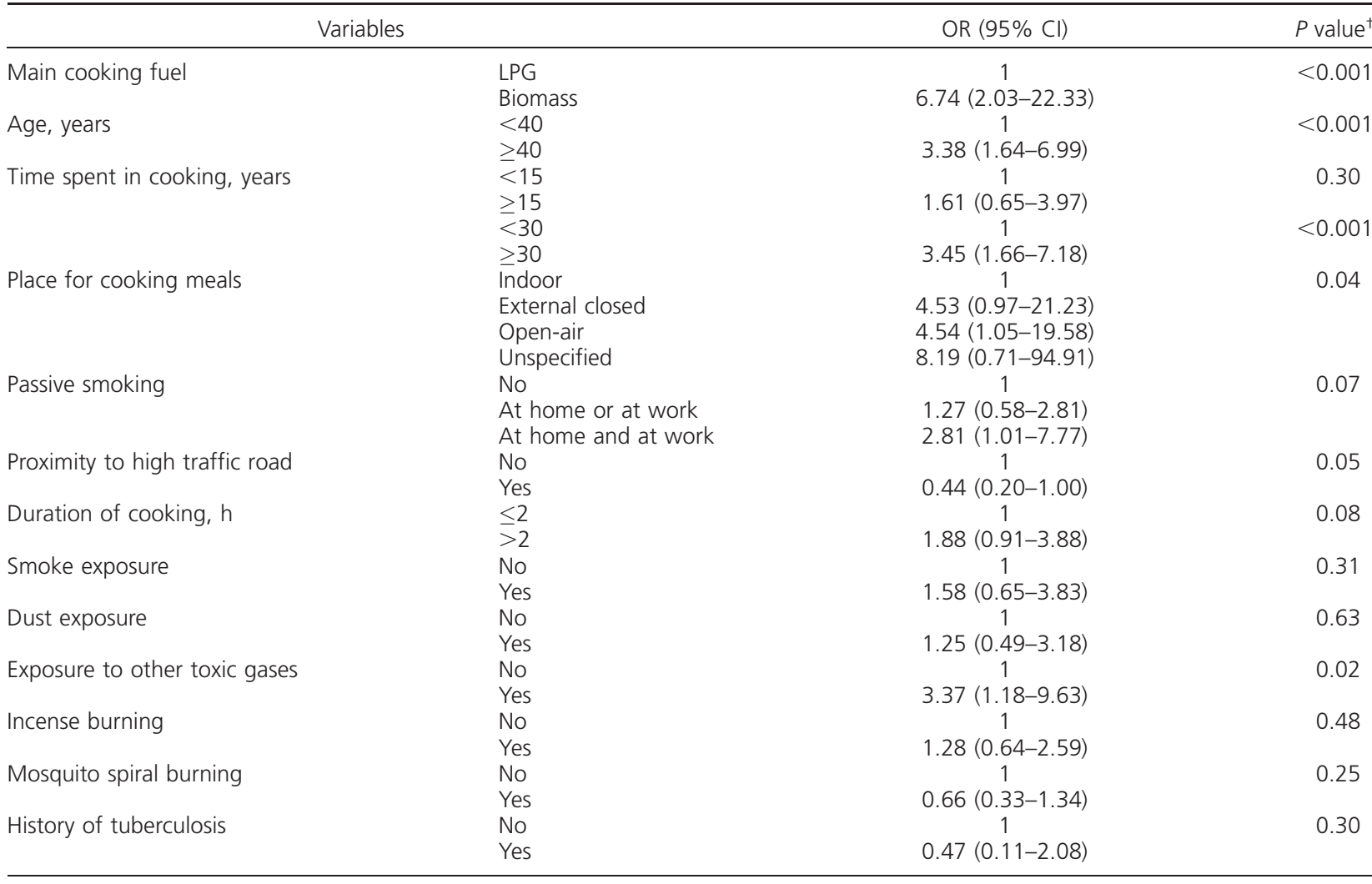

* Biomass $=$ wood and charcoal.

${ }^{+} P<0.05$ considered significant.

$\mathrm{COPD}=$ chronic obstructive pulmonary disease; $\mathrm{OR}=$ odds ratio; $\mathrm{Cl}=$ confidence interval; $\mathrm{LPG}=$ liquefied petroleum gas.

\section{CONCLUSION}

The main findings of the study suggest that exposure to biomass smoke causes respiratory damage among women involved in household cooking activity; this is in in line with previous studies. Interventions to reduce the burden of indoor air pollution due to biomass fuel are thus needed. Enhancing women's knowledge and improving behaviours through participative awareness campaigns about the harmful effect of biomass fuel use can be beneficial. The transition to other forms of energy should be accelerated.

Table 4 Factors associated with COPD and chronic bronchitis in Ouagadougou, Burkina Faso on multivariate analysis $(n=1705$, 1015 biomass users)

\begin{tabular}{|c|c|c|c|}
\hline \multicolumn{2}{|c|}{ Variables } & \multirow{2}{*}{$\frac{\mathrm{aOR}(95 \% \mathrm{Cl})}{1}$} & \multirow[t]{2}{*}{$P$ value } \\
\hline Main cooking fuel & LPG & & \\
\hline & Biomass & $4.54(1.04-19.82)$ & 0.04 \\
\hline \multirow{2}{*}{ Age, years } & $<40$ & 1 & \\
\hline & $\geq 40$ & $1.12(0.21-5.84)$ & 0.89 \\
\hline \multirow[t]{2}{*}{ Time spent in cooking, years } & $\overline{<} 30$ & 1 & \\
\hline & $\geq 30$ & $1.83(0.35-9.46)$ & 0.47 \\
\hline \multirow[t]{4}{*}{ Place for cooking meals } & Internal & 1 & \\
\hline & Closed external & $1.35(0.21-8.71)$ & 0.75 \\
\hline & Outdoors & $0.77(0.12-4.74)$ & 0.78 \\
\hline & Other & $2.58(0.18-37.61)$ & 0.49 \\
\hline \multirow[t]{3}{*}{ Passive smoking } & No & 1 & \\
\hline & At home or at work & $0.59(0.22-1.62)$ & 0.31 \\
\hline & At home and at work & $3.17(0.98-10.22)$ & 0.05 \\
\hline \multirow[t]{2}{*}{ Proximity to high traffic road } & No & 1 & \\
\hline & Yes & $0.84(0.33-2.14)$ & 0.72 \\
\hline \multirow[t]{2}{*}{ Duration of cooking, $\mathrm{h}$} & $\leq 2$ & 1 & \\
\hline & $>2$ & $1.56(0.68-3.58)$ & \\
\hline \multirow[t]{2}{*}{ Exposure to other toxic gases } & No & 1 & \multirow[t]{2}{*}{0.03} \\
\hline & Yes & $3.72(1.16-11.93)$ & \\
\hline
\end{tabular}

* Biomass $=$ wood and charcoal.

$+P<0.05$ considered significant.

$\mathrm{COPD}=$ chronic obstructive pulmonary disease; $\mathrm{aOR}=$ adjusted odds ratio; $\mathrm{Cl}=$ confidence interval; $\mathrm{LPG}=$ liquefied petroleum gas 


\section{Acknowledgements}

The authors thank Université Libre de Bruxelles (ULB; Brussels, Belgium) and to the Health Inter Network Access to Research Initiative (HINARI) team for access to scientific publications; Y Yoin for the detailed English language checking, all study participants for their availability, and all the participating associations and their affiliates for their support. SA was supported by a $\mathrm{PhD}$ studentship granted by the International Development Research Centre (Ottawa, ON, Canada) via the Community of Practice in EcoHealth-West and Central African (CoPEH-WCA), and ULB cooperation funds.

This study was funded by IDRC through the Chairepol Project of CoPEH-WCA (Project IDRC 107347).

Conflicts of interest: none declared.

\section{References}

1 Miranda J J, Kinra S, Casas J P, Davey Smith G, Ebrahim S Non-communicable diseases in low- and middle-income countries: context, determinants and health policy. Trop Med Int Health 2008; 13(10): 1225-1234.

2 World Health Organization. Global Action plan for the prevention and control of noncommunicable diseases, 20132020. Geneva, Switzerland: WHO, 2013.

3 World Health Organization. Preventing noncommunicable diseases (NCDs) by reducing environmental risk factors. Geneva, Switzerland: WHO, 2017.

4 World Health Organization. WHO guidelines for indoor air quality: household fuel combustion. Geneva, Switzerland: WHO, 2014. http://apps.who.int/iris/bitstream/handle/10665/ 141496/9789241548885_eng.pdf? sequence=1.

5 Westhoff B, Germann D. Foyers en images: une documentation sur les foyers améliorés et traditionnels en Afrique, Asie et Amérique Latine. Germany: Commission des Communautés Européennes and Sozietät für Entwicklungsplanung, 1995. [French]

6 Nigel B, Perez-Padilla R, Albalak R. Indoor air pollution in developing countries: a major environmental and public health challenge. Bull World Health Organ 2000; 78(9): 15.

7 Rehfuess E. Énergie domestique et santé: des combustibles pour vivre mieux. Geneva, Switzerland: WHO, 2007. [French]

8 Thorsson S, Holmer B, Andjelic A, Lindén J, Cimerman S, Barregard L. Carbon monoxide concentrations in outdoor wood-fired kitchens in Ouagadougou, Burkina Fasoimplications for women's and children's health. Environ Monit Assess 2014; 186(7): 4479-4492.

9 Kafando B, et al. Pollution interieure par les PM2,5 issues des combustibles utilises pour la cuisson des repas et risques sanitaires dans la ville de Ouagadougou. Environ Risque Sante 2019; 18: 9. [French]

10 World Health Organization. Burning opportunity: clean household energy for health, sustainable development, and wellbeing of women and children. Geneva, Switzerland: WHO, 2016. https://www.who.int/airpollution/publications/burningopportunities/en/.

11 Okello G, Devereux G, Semple S. Women and girls in resource poor countries experience much greater exposure to household air pollutants than men: results from Uganda and Ethiopia. Environ Int 2018; 119: 429-437.

12 World Health Organisation. Chronic obstructive pulmonary disease (COPD). Geneva, Switzerland: WHO, 2016. http: // www.who.int/mediacentre/factsheets/fs315/en/.

13 Cote C G, Chapman K R. Diagnosis and treatment considerations for women with COPD. Int J Clin Pract 2009; 63(3): 486-493.

14 Kurmi O P, Semple S, Simkhada P, Smith W C S, Ayres J G. COPD and chronic bronchitis risk of indoor air pollution from solid fuel: a systematic review and meta-analysis. Thorax 2010; 65: 221-228.

15 Orozco-Levi M, Garcia-Aymerich J, Villar J, RamírezSarmiento A, Antó J M, Gea J. Wood smoke exposure and risk of chronic obstructive pulmonary disease. Eur Respir J 2006; 27(3): 542-546.

16 Sana A, Somda S M A, Meda N, Bouland C. Chronic obstructive pulmonary disease associated with biomass fuel use in women: a systematic review and meta-analysis. BMJ Open Respir Res 2018; 5(1): 10.

17 Akhtar T, Ullah Z, Khan M H, Nazli R. Chronic bronchitis in women using solid biomass fuel in rural Peshawar, Pakistan. Chest 2007; 132(5): 1472-1475.

18 Kim K-H, Jahan S A, Kabir E. A review of diseases associated with household air pollution due to the use of biomass fuels. J Hazard Mater 2011; 192(2): 425-431.

19 Observatoire de la population de Ouagadougou. Rapport scientifique sur la caractérisation sociologique des quartiers de l'OPO. Ouagadougou, Burkina Faso: OPO, 2013. [French]

20 Institut national de la statistique et de la démographie. Annuaire statistique, 2013. Burkina Faso: Institut national de la statistique et de la démographie, 2014. [French]

21 Buist A S, Vollmer W M, McBurnie M A. Worldwide burden of COPD in high- and low-income countries. Part I. The Burden of Obstructive Lung Disease (BOLD) Initiative. Int J Tuberc Lung Dis 2008; 12(7): 703-708.

22 Sana A, Meda N, Badoum G, Kafando B, Bouland C. Primary cooking fuel choice and respiratory health outcomes among women in charge of household cooking in Ouagadougou, Burkina Faso: cross-sectional study. Int J Environ Res Public Health 2019; 16(6): 1040.

23 Global Initiative for Chronic Obstructive Lung Disease. "Could it be COPD?” Questionnaire 2004. Bethesda, MD, USA: GOLD, 2004. http: //www.goldcopd.org/could-it-be-copd. html.

24 Haute Autorité de Santé. Faites le test: aurais-je une BPCO? Saint Denis, France: HAS, 2014. http://www.has-sante.fr/ portail/upload/docs/application/pdf/2014-06/questionnaire depistage_bpco_gold_web.pdf.

25 Calverley P M A, Nordyke R J, Halbert R J, Isonaka S, Nonikov D. Development of a population-based screening questionnaire for COPD. J Chron Obstruct Pulm Dis 2005; 2: 225-232.

26 Labrecque M, Malo J-L, Alaoui K M, Rabhi K. Medical surveillance programme for diisocyanate exposure. Occup Environ Med 2011; 68: 6.

27 Venables K M, Farrer N, Sharp L, Graneek B J, Newman Taylor A J. Respiratory symptoms questionnaire for asthma epidemiology: validity and reproducibility. Thorax 1993; 48: 214-219.

28 Medical Research Council. Definition and classification of chronic bronchitis for clinical and epidemiological purposes. Lancet 1965 ; 285(7389): 775-779.

29 American Thoracic Society. Standardization of spirometry, 1994 update. Am J Respir Crit Care Med 1995; 152(3): 11071136.

30 Sichletidis L, et al. A combination of the IPAG questionnaire and PiKo- $6{ }^{\circledR}$ flow meter is a valuable screening tool for COPD in the primary care setting. Prim Care Respir J 2011; 20(2): 184-189.

31 Mbatchou Ngahane B H, et al. Effects of cooking fuel smoke on respiratory symptoms and lung function in semi-rural women in Cameroon. Int J Occup Environ Health 2015; 21(1): 61-65.

32 Badway M S, Hamed A F, Yousef F M A. Prevalence of chronic obstructive pulmonary disease (COPD) in Qena Governorate. Egypt J Chest Dis Tuberc 2016; 65(1): 29-34.

33 Johnson P, et al. Prevalence of chronic obstructive pulmonary disease in rural women of Tamilnadu: implications for refining disease burden assessments attributable to household biomass combustion. Global Health Action 2011; 4: 7226. 
34 Ramirez-Venegas A, et al. Prevalence of COPD and respiratory symptoms associated with biomass smoke exposure in a suburban area. Int J Chron Obstruct Pulmon Dis 2018; 13: 1727-1734.
35 van Gemert F, et al. Prevalence of chronic obstructive pulmonary disease and associated risk factors in Uganda (FRESH AIR Uganda): a prospective cross-sectional observational study. Lancet Global Health 2015; 3(1): e44-51. 
CADRE : Selon l'OMS, la bronchopneumopathie chronique obstructive (BPCO) deviendra la troisième cause de décès dans le monde en 2030. En Afrique subsaharienne très peu d'études ont analysé le fardeau lié à cette maladie. Cette étude a pour objectif d'estimer la prévalence et les facteurs de risque de la BPCO chez les femmes en charge de la cuisine familiale à Ouagadougou, au Burkina Faso.

MÉTHODE : Une enquête transversale a été conduite dans trois quartiers de la ville d'Ouagadougou de mars 2017 à septembre 2018. L'échantillon était constitué de femmes âgées d'au moins 18 ans, en charge de la cuisine dans leur ménage. La BPCO est définie par un rapport VEMS/CVF (volume expiratoire maximum seconde/ capacité vitale forcée) post-bronchodilatation inférieur à 0,70 et la bronchite chronique est définie par une toux chronique avec des expectorations pendant au moins 3 mois de suite dans l'année et au moins 2 années consécutives.
RÉ SULTATS : Parmi les 1705 femmes interviewées, 835 répondaient aux critères de sélection pour la spirométrie et 564 femmes ont pu réaliser un test valide. La prévalence de la BPCO confirmée par la spirométrie a été estimée à $1,1 \%$ et celle de la bronchite chronique de l'ordre de $1,2 \%$. La prévalence était plus élevée dans le groupe de femmes utilisant de la biomasse comme principal combustible pour la cuisine, les femmes d'âge $\geq 40$ ans, celles avec une ancienneté dans la cuisine supérieure à 30 ans, la préparation des repas à l'air libre et l'exercice d'autre activité exposant à des gaz toxiques. Après ajustement, l'utilisation de la biomasse et l'exercice d'autres activités exposant à des produits toxiques restent les facteurs associés à la BPCO.

CONCLUSION : Il est plus qu'urgent de mettre en place des stratégies afin d'accélérer la transition énergétique.
MARCO De REFEREnCIA: Según la OMS, en el 2030 la enfermedad pulmonar obstructiva crónica (EPOC) se convertirá en la tercera causa de muerte. En África subsahariana se desconoce la carga de morbilidad por EPOC. Se evaluó la prevalencia y los factores asociados con la EPOC y la bronquitis crónica en las mujeres encargadas de cocinar en los hogares.

MÉTODO: Se llevó a cabo una encuesta poblacional transversal. Se escogieron de manera aleatoria mujeres a partir de los 18 años, encargadas de cocinar en sus hogares. Se definió la EPOC como un $\mathrm{FEV}_{1} / \mathrm{FVC}$ (flujo espiratorio forzado medio en un segundo/capacidad vital forzada) posbroncodilatador inferior a 0,70 y la bronquitis crónica se definió como la presencia de tos con producción de esputo por lo menos durante 3 meses al año, como mínimo 2 años consecutivos.
RESUMEN

RESULTADOS: Se entrevistaron 1705 mujeres, de las cuales se escogieron 835 para realizar la espirometría y se obtuvieron pruebas aceptables en 564 de ellas. La prevalencia de EPOC fue 1,1\% y la de bronquitis crónica fue $1,2 \%$. La prevalencia de EPOC fue más alta en las mujeres que utilizaban combustibles de biomasa, las mujeres mayores de 40 años, las que llevaban más de 30 años cocinando y las mujeres que practicaban otras actividades que exponen a gases tóxicos. Tras el ajuste, solo el uso de combustibles de biomasa y la práctica de otras actividades que exponen a productos tóxicos conservaron la asociación con la EPOC.

CONCLUSIÓN: Se precisan medidas urgentes encaminadas a acelerar la transición energética. 
Queries for jtld-24-09-16

This article has been typeset from the submitted materials. Check proofs carefully for conversion or other inadvertent errors. Please follow the Allen Press Guide to PDF Annotation when marking revisions. Do not edit the PDF directly.

If present, queries will be listed below with corresponding numbers in the margins or may appear as PDF comments addressed to the author or editor. If a correction is desired in response to a query, mark the necessary changes directly in the proof using the appropriate annotation tool. If no change is desired, no action is necessary in response.

1. Author: please provide place (city) of publication. Ed 